\title{
Taxonomy, Conservation, and the Future of Native Aquatic Snails in the Hawaiian Islands
}

\author{
Carl C. Christensen ${ }^{1,2}$, Kenneth A. Hayes ${ }^{1,2, *(D)}$ and Norine W. Yeung ${ }^{1,2}$ \\ 1 Bernice Pauahi Bishop Museum, Honolulu, HI 96817, USA; carl.christensen@bishopmuseum.org (C.C.C.); \\ nyeung@hawaii.edu (N.W.Y.) \\ 2 Pacific Biosciences Research Center, University of Hawaii, Honolulu, HI 96822, USA \\ * Correspondence: kenneth.hayes@bishopmuseum.org
}

Citation: Christensen, C.C.; Hayes,

K.A.; Yeung, N.W. Taxonomy,

Conservation, and the Future of

Native Aquatic Snails in the

Hawaiian Islands. Diversity 2021, 13,

215. https://doi.org/10.3390/

d13050215

Academic Editors: Russell Minton

and Luc Legal

Received: 15 April 2021

Accepted: 14 May 2021

Published: 18 May 2021

Publisher's Note: MDPI stays neutral with regard to jurisdictional claims in published maps and institutional affiliations.

Copyright: (c) 2021 by the authors. Licensee MDPI, Basel, Switzerland. This article is an open access article distributed under the terms and conditions of the Creative Commons Attribution (CC BY) license (https:// creativecommons.org/licenses/by/ $4.0 /)$.

\begin{abstract}
Freshwater systems are among the most threatened habitats in the world and the biodiversity inhabiting them is disappearing quickly. The Hawaiian Archipelago has a small but highly endemic and threatened group of freshwater snails, with eight species in three families (Neritidae, Lymnaeidae, and Cochliopidae). Anthropogenically mediated habitat modifications (i.e., changes in land and water use) and invasive species (e.g., Euglandina spp., non-native sciomyzids) are among the biggest threats to freshwater snails in Hawaii. Currently, only three species are protected either federally (U.S. Endangered Species Act; Erinna newcombi) or by Hawaii State legislation (Neritona granosa, and Neripteron vespertinum). Here, we review the taxonomic and conservation status of Hawaii's freshwater snails and describe historical and contemporary impacts to their habitats. We conclude by recommending some basic actions that are needed immediately to conserve these species. Without a full understanding of these species' identities, distributions, habitat requirements, and threats, many will not survive the next decade, and we will have irretrievably lost more of the unique books from the evolutionary library of life on Earth.
\end{abstract}

Keywords: Pacific Islands; Gastropoda; endemic; Lymnaeidae; Neritidae; Cochliopidae

\section{Introduction}

Freshwater ecosystems are negatively impacted by anthropogenic threats and almost one in three freshwater species is threatened with extinction [1]. This extinction plight is well reflected in freshwater molluscan faunas [2]. Globally, the number of freshwater molluscs threatened with extinction varies, with 44\% in Europe [3], 29\% in Africa [4] and 17\% in Indo-Burma [5]. More than a decade ago at least two-thirds of all species of unionid mussels from Canada and the United States were listed as extinct, possibly extinct, critically imperiled, imperiled, or vulnerable [6], and nearly $41 \%$ of all freshwater mussel species assessed by the IUCN are considered Near Threatened, Vulnerable, Endangered, or Critically Endangered [7]. The conservation status of nearly 100\% of mammal and bird species is known, but only $7 \%$ of mollusc species have conservation status assessments by IUCN and the extinction rate for poorly studied molluscs is probably orders of magnitude greater than currently estimated [8-11]. Many of these unrecorded extinctions are occurring on Pacific Islands such as Hawaii [12-14].

The Hawaiian archipelago is one of the most isolated landmasses in the world, with California over $3700 \mathrm{~km}$ to the northeast and Japan nearly $6000 \mathrm{~km}$ to the westnorthwest [15]. The Hawaiian Islands have a small but highly specialized native stream fauna (Figure 1), and colonizers have reached these islands by dispersal through or over substantial expanses of ocean, either as planktonic veligers or as passive hitchhikers on migrating birds or other dispersal vectors $[15,16]$. 


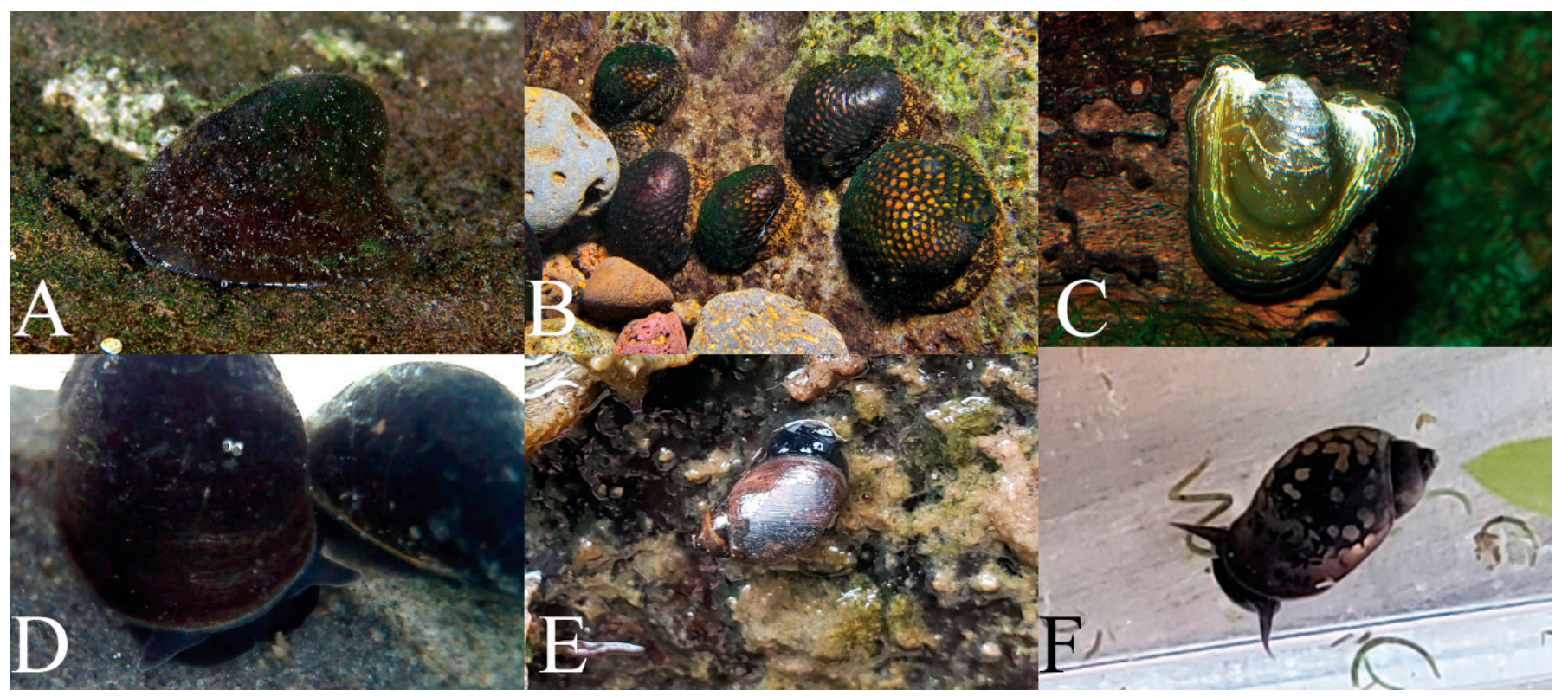

Figure 1. Live representatives of Hawaii's endemic freshwater snail fauna. (A) Neripteron cariosum (Wood, 1828), (B) Neritona granosa (Sowerby, 1825), (C) and Neripteron vespertinum (Sowerby, 1849), (D) Erinna newcombi H. Adams and A. Adams in A. Adams, 1855, (E,F) Pseudosidora c.f. producta (Mighels, 1845) in its natural seep habitat (E) and in artificial habitat in the laboratory (F). Photo credits: (A-C) Keoki Stender, (D) Gordon Smith, U.S. Fish and Wildlife Service, and (E,F) Kenneth Hayes.

Hawaiian streams are highly variable in flow, spatially and temporally, with sudden peaks and long troughs in flow rates. Peak flows aid the flushing of debris from the streambeds, which in turn signal to aquatic organisms to migrate and spawn [15-18]. Native Hawaiian stream species have adapted to these variable conditions, and many, but not all, non-native species are unable to survive in these freshwater habitats [16]. Adaptations in native species include freshwater fish with fused pelvic fins that allow them to cling to substrate during torrential flows or to climb waterfalls, and several native stream fishes, crustaceans, and molluscs are amphidromous [19-22]. Unfortunately, many of the low-elevation freshwater habitats in the islands have been heavily impacted by development and are dominated by introduced species, leaving the remaining native taxa to seek refuge in the less impacted upper elevations reaches [23]. In turn, higherelevation habitats are impacted by the alteration of the lower reaches, making even the upper-elevation refuges susceptible to invasion and impacts of introduced species.

Although the Hawaiian aquatic malacofauna is small, eight recognized species are present in three families: Neritidae, Lymnaeidae, and Cochliopidae. The fauna is highly endemic, and native species inhabit various fresh- and brackish-water habitats from estuaries and coastal ponds to freshwater springs and seeps. Here, we provide a taxonomic overview of the Hawaiian freshwater molluscs, the impacts that have reduced their numbers, their conservation status, and what steps must be taken to conserve them now and in the future.

\section{Taxonomic Overview of the Fauna}

Within the Neritidae, there are three endemic species; two of these, Neripteron vespertinum (Sowerby, 1849) and N. cariosum (Wood, 1828), are euryhaline and inhabit coastal ponds, anchialine pools, stream mouths, and estuaries [24,25]. The third species, Neritona granosa (Sowerby, 1825), is anadromous (Figure 2). Adults of this species live in clear steep-gradient streams from sea level to at least $400 \mathrm{~m}$ in elevation, and planktonic larvae develop in the sea before returning to freshwater environments [24,26,27]. Eggs are attached to boulders in the streams or to the shells of other snails; upon hatching, the larvae are washed out to sea where they remain in the plankton for an undetermined period, after which they enter and crawl upstream where they grow to adulthood [20,27]. 
These freshwater neritids, especially N. granosa, are of considerable cultural significance to native Hawaiians as food items; Hawaiian names for N. vespertinum, N. cariosum, and N. granosa are, respectively, hapawai, pipiwai, and hïhīwai [28-30]. While N. granosa and N. vespertinum have been the subject of population genetic studies [20,31], there have been no modern systematic assessments incorporating molecular data that included all three species in Hawaii. Hawaiian taxa have not been included in the few studies attempting to assess relationships among the Neritidae in a modern systematic framework [32-34], and as such the details of their evolution and relationships to one another and other nerites remain uncertain. This knowledge gap impedes development of effective conservation strategies [35-38].

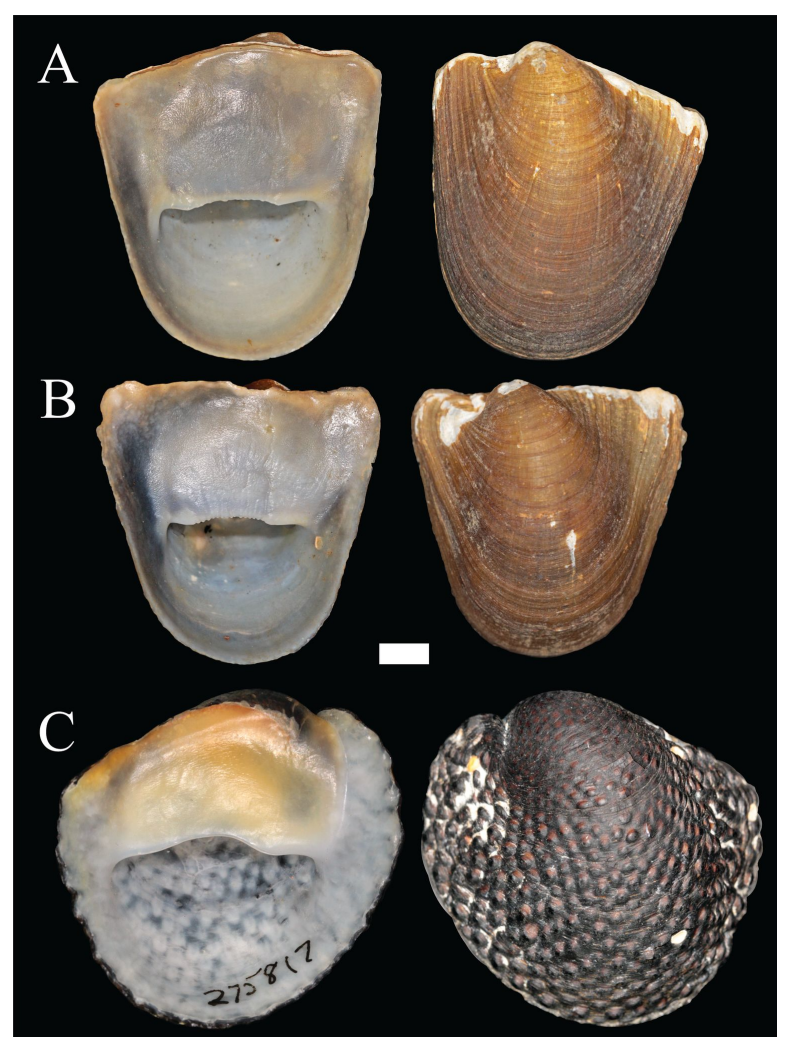

Figure 2. Specimens of Hawaiian Neritidae in the Malacology Collection of the Bernice Pauahi Bishop Museum. (A) Neripteron cariosum (Wood, 1828) BPBM288518, (B) Neripteron vespertinum (Sowerby, 1849) BPBM288519, and (C) Neritona granosa (Sowerby, 1825) BPBM275817. Scale bar $=5 \mathrm{~mm}$.

Historically, four species of endemic lymnaeids have been recognized in Hawaii, Erinna newcombi H. Adams and A. Adams in A. Adams, 1855, E. aulacospira (Ancey, 1889), Pseudisidora producta (Mighels, 1845), and P. rubella (Lea, 1841) and have been reported primarily to inhabit the islands' streams (Figure 3) $[39,40]$. The last taxonomic monograph of the Hawaiian lymnaeids was by Hubendick [41], some of the flaws of which have been noted by Morrison [42], and the Hawaiian representatives of the family need a systematic revision and modern taxonomic assessment. Unfortunately, little is known regarding their ecology, evolution, or relationships to other Lymnaeidae globally. The few species that have been observed in recent times appear primarily to inhabit the spray zones at the edges of waterfalls or other marginal habitats (e.g., seeps), which may be a factor contributing to their dramatic declines. Except for Erinna newcombi, which is listed as threatened under the US Endangered Species Act [43] and as vulnerable on the IUCN Red List [44], none of the Hawaiian lymnaeids has been assessed for their conservation status. 


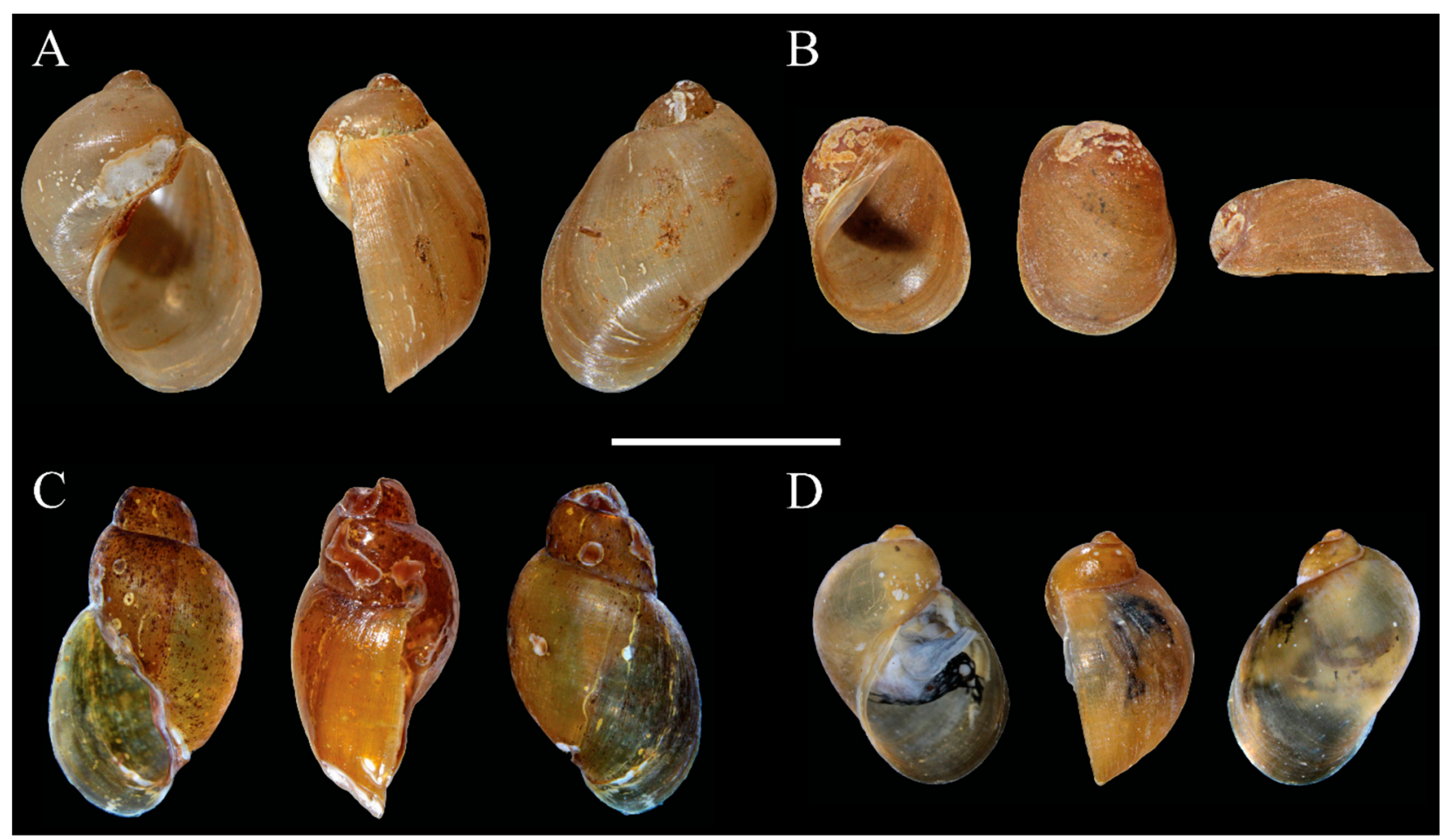

Figure 3. Specimens of Hawaiian Lymnaeidae in the Malacology Collection of the Bernice Pauahi Bishop Museum. (A) E. aulacospira (Ancey, 1889) BPBM14797, (B)Erinna newcombi H. Adams \& A. Adams in A. Adams, 1855 BPBM15571, (C) Pseudisidora producta (Mighels, 1845) BPBM288520, and (D) Pseudisidora rubella (Lea, 1841) BPBM288521. Scale bar $=5 \mathrm{~mm}$.

Notable among Hawaiian lymnaeids is the invariably sinistral species Pseudisidora producta. However, preliminary data from phylogenetic analyses indicate that there are possibly two sinistral species occurring in the Hawaiian Islands, and other cryptic taxa that need evaluation. Unfortunately, less than 50 individuals belonging to the two sinistral species have been recorded in the last 20 years, and since 2015 we have only recorded three Pseudisidora producta from a single location on Kauai and fewer than 30 of the other sinistral species on Oahu (Hayes \& Yeung unpublished). These species, like most of the lymnaeids in Hawaii, are found in waterfall spray zones, seeps, and other highly ephemeral habitats that are readily impacted by alternations to water supplies or climate.

Finally, one species of the hydrobioid family Cochliopidae, Tryonia porrecta (Mighels, 1845) (Figure 4), formerly abundant in coastal ponds and irrigated wetlands but now nearly extirpated [45], has been shown by Hershler [46] to be conspecific with a North American snail long known as T. protea (Gould, 1855). Its status as indigenous in the Hawaiian Islands has only recently been supported through examination of subfossil material from paleoenvironmental investigations [45,47-49]. Little is known about this species ecology, distributions, or evolution, and like other freshwater taxa in Hawaii it would benefit from modern surveys and studies of other aspects of their biology to better assess their conservation status. 


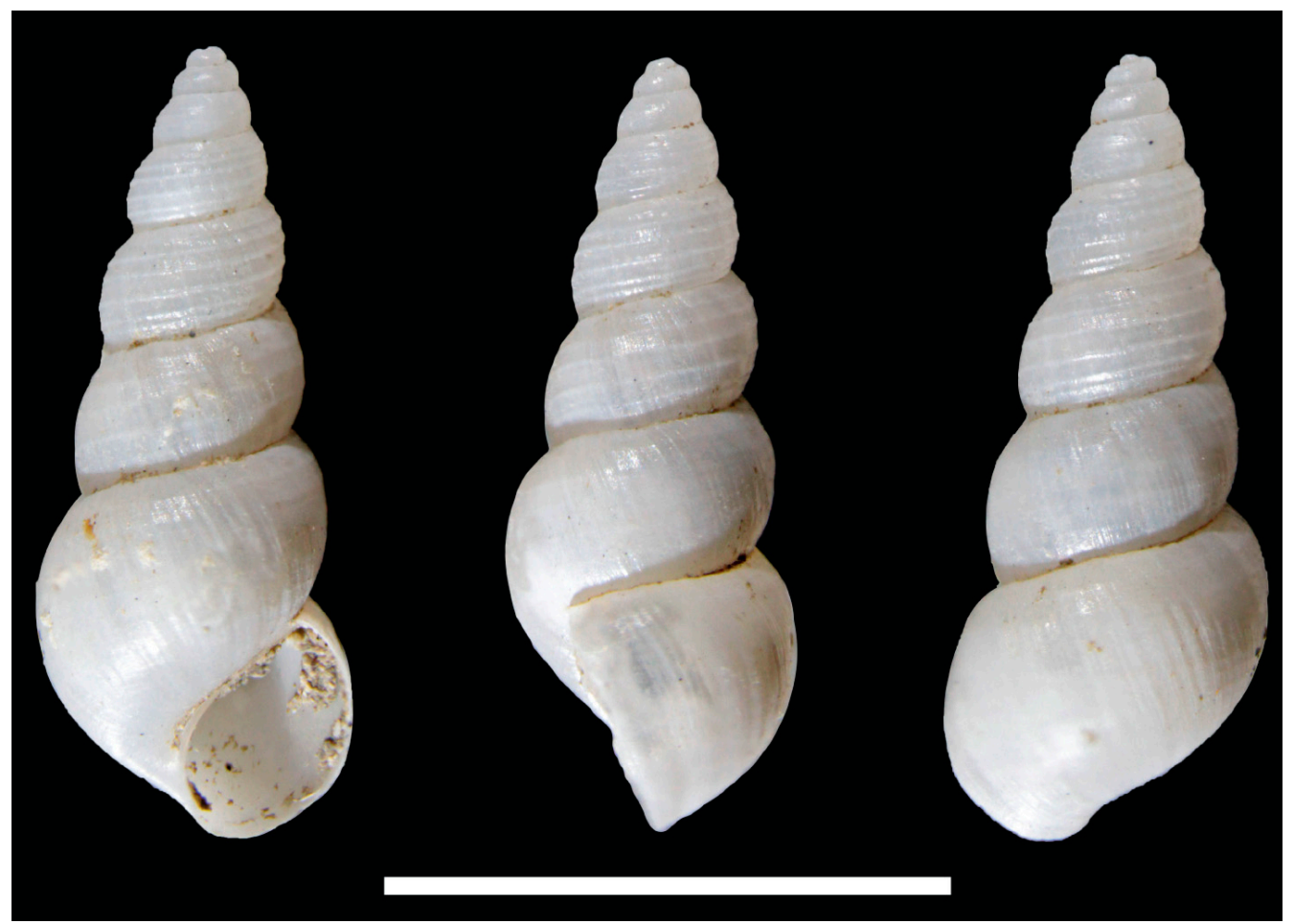

Figure 4. Specimen of Hawaiian Cochliopidae, Tryonia porrecta (Mighels, 1845) BPBM277027. Scale bar $=5 \mathrm{~mm}$.

In addition to these indigenous species, Cowie [50] listed more than a dozen nonnative species of aquatic snails in the families Ampullariidae, Bithyniidae, Lymnaeidae, Physidae, Planorbidae, Thiaridae, and Viviparidae that have become established in Hawaii since their initial human settlement a thousand or so years ago [51,52]. Christensen [53] noted the presence of three alien bivalves, two sphaeriids and the ubiquitous cyrenid Corbicula fluminea (O.F. Müller, 1774). A few species are known to be so-called "canoe" species, Melanoides tuberculata (Müller, 1774) and Tarebia granifera (Lamarck, 1816), no doubt introduced as stowaways with the prehistoric voyages of the Polynesians [54], while other non-native species have been introduced by modern commerce from the mid-19th century to the present [50,55]. In addition to those species listed by Cowie [50] our recent survey and taxonomic assessments of introduced species have revealed at least three new species of freshwater snails, two lymnaeids and one physid (Christensen et al. unpublished; Hayes et al. unpublished).

\section{Negative Impacts to Native Freshwater Snails}

The conservation status of the Hawaiian freshwater fauna is intimately intertwined with the effects of human-induced habitat alterations (i.e., changes in land and water use since initial human settlement) and the impacts of invasive species. All of Hawaii's native freshwater gastropods are threatened with extinction or are much reduced in range. As discussed below, the principal threats are the dewatering of streams for irrigation and other off-stream uses, habitat loss as a result of land development, and the spread of alien species, especially biocontrol agents intentionally introduced for the control of other nonmarine molluscs. While not yet assessed fully, continued climate change may exacerbate these already detrimental impacts, making these already imperiled species more vulnerable.

\section{Habitat Alteration}

Polynesians settled the Hawaiian Islands approximately one thousand years ago [51,52], bringing with them a number of plants and animals and substantially modifying the islands' lowlands through their own activities and the actions of their accompanying commensals, especially the Polynesian rat, Rattus exulans (Peale, 1848) [56-58], resulting in the extinc- 
tion of many species of native birds and land snails $[59,60]$. Native lymnaeids living in mountain streams may have been only minimally impacted initially, as those environments were little modified by human activities [56]. In the lower reaches of streams, juveniles of the native neritids had previously been subject to predation by native fish and crustaceans, a situation that did not change with human settlement. Adult neritids had few predators other than the native, black-crowned night heron Nycticorax nycticorax hoactli (Gmelin, 1789) and other shorebirds [24,26], and their numbers were no doubt decreased because of their use as food by the Hawaiians, but all three species continued to exist in fair numbers on all islands except Oahu in the 1970s [24], although recent fieldwork (Hayes \& Yeung unpublished) suggests their numbers may have decreased since then. Two nonnative thiarid snails, Melanoides tuberculata (Müller, 1774) and Tarebia granifera (Lamarck, 1816), were introduced prehistorically [54], but their presence in coastal wetlands and the lower reaches of watercourses did not adversely affect Tryonia porrecta as the three species co-occurred in abundance until the early 20th-century near-extirpation of Tryonia [45,54]. These thiarids are abundant in the lower reaches of Hawaiian streams, but their ranges do not extend into the higher-elevation streams inhabited by adult $N$. granosa and native lymnaeids.

The pre-European contact Hawaiian economy was based primarily on cultivation of kalo (taro, Colocasia esculenta (L.) Schott) in lo'i (irrigated terraces or paddies) in valley bottoms, and to this end substantial irrigated wetlands were created [61-63]. While the Hawaiians did divert water out of streams for irrigation of kalo, the diversions did not take all the water in the stream [61]. Return flows reverted to the stream of origin after use and unlike later out-of-watershed diversions for sugar irrigation, did not totally dewater streams so as to impede upstream migration by juveniles of anadromous stream fauna such as $N$. granosa. Indeed, Hawaiian irrigation practices were undoubtedly advantageous to some native taxa. Olson and James [64] noted that native water birds benefited from the increased area of lowland wetlands associated with kalo irrigation, and Tryonia porrecta would have received the same benefit. That species remained abundant in cultivated lowland wetlands throughout the Islands until the early 1900s [45].

From the mid-19th to mid-20th centuries, the sugar industry was the basis of the Hawaiian economy. Sugar cultivation requires great quantities of water for irrigation, and elaborate systems of ditches and flumes to move water from wet windward valleys to the arid leeward flatlands where sugar could be cultivated on vast plantations [65-67]. This resulted in the almost complete dewatering of many windward streams and substantial reduction in available habitat for aquatic fauna such as $N$. granosa $[16,27,68,69]$ and $E$. newcombi $[70,71]$. Climate change is also causing a decrease in stream flows, with possible adverse effects on native aquatic species [72].

Recent archaeological studies ([45] Christensen unpublished) demonstrate that T. porrecta remained abundant until shortly after the turn of the 20th century. Rapid urbanization, beginning in the late 19th century and most intensely on the island of Oahu, resulted in the destruction of many of the lowland wetlands formerly in cultivation for kalo or rice. An estimated $44 \%$ of pre-settlement wetlands have been lost in the islands, and on Oahu the loss is much higher at $65 \%$ of wetlands [73]. Living T. porrecta have been observed in the Hawaiian Islands on only three occasions in the last 75 years, twice in coastal ponds on the island of Hawaii and once in a nursery on Oahu ([45], Christensen unpublished, Hayes \& Yeung unpublished). It is the destruction of suitable habitat that accounts for this near extirpation, not its mere degradation, as T. porrecta can survive in artificial wetlands as demonstrated by the recent discovery of thriving populations of the species in two artificial lakes in Phoenix, Arizona [74].

\section{Impacts of Non-Native Species}

Since the rediscovery of the Hawaiian Islands by Captain James Cook in 1778, numerous alien animal species have become established in Hawaiian streams and other wetlands, including 37 species of fish and three species of crustaceans [23,75,76]. As noted 
above, Hawaii's aquatic fauna now includes numerous alien gastropods and a few bivalves. Cowie [77] suggested that alien freshwater molluscs may adversely impact native species, although the extent and mechanisms of such impacts are poorly studied. Alien caddisflies, fish, and amphibians are believed to prey on native aquatic live, including E. newcombi [43] and, undoubtedly, other endemic lymnaeids. Ford [26] discounted predation by alien species as a threat to N. granosa.

Snails and insects introduced as biocontrol to the Hawaiian Islands are noted as considerable threats to the survival of the endemic lymnaeid snail Erinna newcombi [43], and no doubt to other native lymnaeids as well. Agricultural authorities in Hawaii have long been active proponents of biological control efforts targeting various pest species [78], until recently with little consideration for impacts on non-target species. Predatory land snails such as those belonging to the Euglandina rosea (Férussac, 1821) species complex [79], introduced to Hawaii in 1955 in an unsuccessful effort to control the Giant African Snail Lissachatina fulica (Bowdich, 1822) have been implicated in the extinction of numerous endemic land snail species in Hawaii and elsewhere in the Pacific [13,80-82]. These species frequently occur in locations inhabited by native Hawaiian lymnaeids and have been observed to prey on them in laboratory experiments [83]. Euglandina spp. are regarded also as a serious threat to the survival of E. newcombi [43].

Flies of the family Sciomyzidae parasitize and kill nonmarine snails, and beginning in 1958, the Hawaii Department of Agriculture released eleven species of sciomyzids in an attempt to control of the alien aquatic lymnaeid snails Orientogalba viridis (Quoy \& Gaimard, 1833), formerly known as Lymnaea ollula (Gould, 1859), and Pseudosuccinea columella (Say, 1817), the principal intermediate hosts in Hawaii of the liver fluke Fasciola gigantica Cobbold, 1855, the causative agent of fascioliasis in cattle and, occasionally, in humans [84]. Two species of these flies have become established in the Hawaiian Islands [78,85]. Non-native sciomyzids are established in locations currently or formerly inhabited by native lymnaeids and have also been recognized as serious threats to native lymnaeid [70].

\section{Conservation Outlook}

\subsection{Federal and State Legal Protection}

The US Federal and Hawaii state laws provide protection to Hawaii's native freshwater molluscs [86]. The most notable of these are the U.S. Endangered Species Act (ESA, 16 United States Code $\S \S 1531$ et seq.), and the analogous provisions of Hawaii state law (Chapter 195D, Hawaii Revised Statutes [HRS]) that provide specific protection to certain species of endemic aquatic snails, specifically Erinna newcombi, Neritona granosa, and Neripteron vespertinum. Erinna newcombi is listed as "threatened" under the ESA [70] which also protects it under state law (Chapter 195D, HRS). Neritona granosa and Neripteron vespertinum receive specific protection under state law because of their cultural significance and the commercial sale of these species is prohibited ( $\$ 188-42.5$, HRS). Article XII, Section 7 of the Constitution of the State of Hawaii protects rights "customarily and traditionally exercised for subsistence, cultural and religious purposes" by Native Hawaiians, and the State Water Code, $\$ 174 \mathrm{C}-101(\mathrm{c})$, lists the gathering of $N$. granosa as among those protected rights. Additionally, all native lymnaeids and aquatic neritids receive additional protection as they are listed in the Hawaii Department of Land and Natural Resources' Wildlife Action Plan [87], a document intended to guide state and local agencies in conservation actions that may affect these species. Accordingly, federal and state agencies must consider potential impacts on these species when making decisions regarding land and water use.

The demise of Hawaii's sugar industry in the late 20th century allowed the reallocation of large amounts of water previously used for irrigation of sugar lands to various consumptive and non-consumptive uses $[29,66]$ by state and county agencies. The reallocations have become highly controversial $[28,66,88-90]$ as Native Hawaiian gathering rights protected under state law, including the need to preserve instream flows essential to the upstream migration of hihiwai and other anadromous stream fauna, have been at issue in other litigation involving lands on multiple main Hawaiian Islands $[29,66,90]$. 
The potential presence of protected lymnaeid and/or neritid snails must be addressed in environmental disclosure documents supporting proposals for development projects that may affect these species and thus these legal requirements have real world consequences (e.g., $[91,92])$.

\subsection{The Future of Freshwater Snail Conservation in Hawaii}

Böhm et al. [2] reviewed the conservation status of a random sample of 1500 of the world's freshwater molluscs and determined that approximately one-third of all species are threatened with extinction. Despite the seemingly extensive legal protections for freshwater snails in Hawaii, this highly endemic fauna continues to decline, and the lack of ecological, evolutionary, and taxonomic studies on these groups limit the incorporation of critical scientific data needed for the development of effective conservation plans. Prospects for Hawaii's lowland wetlands have been reviewed by Browning et al. [18] and Kim et al. [86] under a variety of proposed management regimes; it is predicted that these environments will continue to be degraded unless active measures are instituted to restore and expand these valuable wetlands. Unless affirmative measures, including potentially the captive rearing of native lymnaeids, are undertaken we estimate that some species of Hawaiian freshwater snails are unlikely to survive the next few decades.

As was the case with Hawaiian land snails prior to 2010 [12,93], very few comprehensive surveys of native freshwater snails have been carried out in the last 60 years. Field surveys during the 1990s primarily targeted Erinna newcombi, leading to it being federally listed in 2000 and the conservation status of the remaining freshwater molluscs remain unknown. In 1990, Solem [12] provided actions needed to conserve Hawaii's remaining land snails. These included (1) surveys to identify where native snails persist; (2) identification of immediate threats to species and their populations; (3) protection and restoration of habitats; (4) updating taxonomic and distributional status of extant species. Since 2011, more than 1000 surveys have been conducted across the main Hawaiian Islands in search of Hawaii's native land snails, in which more than 200 species have been recorded or rediscovered, with several species new to science (e.g., [93-95]; approximately 75 species were estimated to persist prior to this endeavor. Similar efforts need to be supported for evaluation of freshwater snails in Hawaii, and the actions outlined by Solem [12] and amended by Yeung and Hayes [93] should be implemented immediately to thoroughly update the systematic and conservation status of this highly threatened freshwater fauna. Without such data, appropriate and effective conservation measures are not possible, and it is almost a certainty that many of the remaining species will be lost forever.

Author Contributions: Conceptualization, C.C.C., K.A.H. and N.W.Y.; funding acquisition, K.A.H. and N.W.Y.; investigation, C.C.C., K.A.H. and N.W.Y.; project administration, N.W.Y.; resources K.A.H.; supervision, C.C.C., K.A.H. and N.W.Y.; writing-original draft, C.C.C., K.A.H. and N.W.Y.; writing-review and editing, C.C.C., K.A.H. and N.W.Y. All authors have read and agreed to the published version of the manuscript.

Funding: The work that made this review possible was supported through grants awarded to K.A.H. and N.W.Y. from the National Science Foundation (DEB-1656254, 1656231, 1837849) and US Fish and Wildlife Service (F20AC11607).

Institutional Review Board Statement: Not applicable.

Informed Consent Statement: Not applicable.

Data Availability Statement: Data sharing not applicable.

Acknowledgments: We thank all the members of the malacology crew at the Bishop Museum for their dedication to the study and conservation of non-marine snails in Hawaii. We are especially grateful to Jaynee Kim for reviewing early drafts of the manuscript and her assistance with formatting. We also appreciate Taylor Maruno and Andy Huang for helping with imaging of museum specimens. This is contribution 2021-004 of the Hawaii Biological Survey of Bishop Museum. 
Conflicts of Interest: From 1991 to 2001, C.C.C. was employed as an attorney representing Native Hawaiian kalo farmers seeking to restore instream flows in streams on $\mathrm{O}^{\prime}$ ahu and Maui through proceedings before administrative agencies of the State of Hawaii and the Hawaii Supreme Court, including the Maui streams that subsequently became the subject of Alexander \& Baldwin [91]. The authors declare no other conflict of interest.

\section{References}

1. Collen, B.; Whitton, F.; Dyer, E.E.; Baillie, J.E.M.; Cumberlidge, N.; Darwall, W.R.T.; Pollock, C.; Richman, N.I.; Soulsby, A.M.; Böhm, M. Global patterns of freshwater species diversity, threat and endemism. Glob. Ecol. Biogeogr. 2014, 23, 40-51. [CrossRef] [PubMed]

2. Böhm, M.; Dewhurst-Richman, N.I.; Seddon, M.; Ledger, S.E.H.; Albrecht, C.; Allen, D.; Bogan, A.E.; Cordeiro, J.; Cummings, K.S.; Cuttelod, A.; et al. The conservation status of the world's freshwater molluscs. Hydrobiologia 2020, 12, 1-24. [CrossRef]

3. Cuttelod, A.; Seddon, M.; Neubert, E. European Red List of Non-Marine Molluscs; Publications Office of the European Union: Luxembourg, 2011; ISBN 978-92-79-20198-1.

4. Seddon, M.; Appleton, C.; Van Damme, D.; Graf, D. Freshwater molluscs of Africa: Diversity, distribution, and conservation. In The Diversity of Life in African Freshwaters: Underwater, under Threat. An Analysis of the Status and Distribution of Freshwater Species throughout Mainland Africa; Darwall, W., Smith, K., Allen, D., Holland, R., Harrison, I., Brooks, E., Eds.; IUCN: Cambridge, UK; Gland, Switzerland, 2011; pp. 92-125, ISBN 978-2-8317-1345-8.

5. Köhler, F.; Seddon, M.; Bogan, A.E.; Van Tu, D.; Sri-Aroons, P.; Allen, D. The status and distribution of freshwater molluscs of the Indo-Burma region. In The Status and Distribution of Freshwater Biodiversity in Indo-Burma; Allen, D.J., Smith, K.G., Darwall, W.R.T., Eds.; IUCN: Cambridge, UK; Gland, Switzerland, 2012; pp. 66-88, ISBN 978-2-8317-1424-0.

6. Lydeard, C.; Cowie, R.H.; Ponder, W.F.; Bogan, A.E.; Bouchet, P.; Clark, S.A.; Cummings, K.S.; Frest, T.J.; Gargominy, O.; Herbert, D.G.; et al. The global decline of nonmarine mollusks. BioScience 2004, 54, 321-330. [CrossRef]

7. Ferreira-Rodríguez, N.; Akiyama, Y.B.; Aksenova, O.V.; Araujo, R.; Barnhart, M.C.; Bespalaya, Y.V.; Bogan, A.E.; Bolotov, I.N.; Budha, P.B.; Clavijo, C.; et al. Research priorities for freshwater mussel conservation assessment. Biol. Conserv. 2019, $231,77-87$. [CrossRef]

8. Rosenberg, G. A new critical estimate of named species-level diversity of the recent Mollusca. Am. Malacol. Bull. 2014, 32, 308-322. [CrossRef]

9. Régnier, C.; Fontaine, B.; Bouchet, P. Not knowing, not recording, not listing: Numerous unnoticed mollusk extinctions. Conserv. Biol. 2009, 23, 1214-1221. [CrossRef] [PubMed]

10. Régnier, C.; Achaz, G.; Lambert, A.; Cowie, R.H.; Bouchet, P.; Fontaine, B. Mass extinction in poorly known taxa. Proc. Natl. Acad. Sci. USA 2015, 112, 7761-7766. [CrossRef] [PubMed]

11. Cowie, R.H.; Régnier, C.; Fontaine, B.; Bouchet, P. Measuring the sixth extinction: What do mollusks tell us? Nautilus 2017, 131, $3-41$.

12. Solem, A. How many Hawaiian land snail species are left? and what we can do for them. Bishop Mus. Occas. Pap. 1990, 30, 27-40.

13. Hadfield, M.G.; Miller, S.E.; Carwile, A.H. The decimation of endemic Hawaiian tree snails by alien predators. Am. Zool. 1993, 33, 610-622. [CrossRef]

14. Régnier, C.; Bouchet, P.; Hayes, K.A.; Yeung, N.W.; Christensen, C.C.; Chung, D.J.D.; Fontaine, B.; Cowie, R.H. Extinction in a hyperdiverse endemic Hawaiian land snail family and implications for the underestimation of invertebrate extinction. Conserv. Biol. 2015, 29, 1715-1723. [CrossRef]

15. Harrington, C.L.; Pang, B.K.; Richardson, M.; Machida, S. Physical geography of the Hawaiian Islands. In Encyclopedia of the World's Biomes; Goldstein, M.I., DellaSalla, D.A., Eds.; Elsevier: Amsterdam, The Netherlands, 2021; Volume 1, pp. 145-156.

16. Brasher, A.M.D. Impacts of human disturbances on biotic communities in Hawaiian streams. BioScience 2003, 53, 1052-1060. [CrossRef]

17. Stone, C.P. Hawaii's wetlands, streams, fishponds, and pools. In Conservation Biology in Hawaii; Stone, C.P., Stone, D.B., Eds.; University of Hawaii Cooperative National Park Resources Studies Unit: Honolulu, HI, USA, 1989; pp. 125-136, ISBN 0-82481206-9.

18. Browning, J.H.; Reeves, M.; Amidon, F.; Miller, S. Hawaii: The wetland system of Hawaii. In Encyclopedia of the World's Biomes; Goldstein, M.I., DellaSalla, D.A., Eds.; Elsevier: Amsterdam, The Netherlands, 2021; Volume 4, pp. 211-234.

19. Kinzie, R.A. Habitat utilization by Hawaiian stream fishes with reference to community structure in oceanic island streams. Environ. Biol. Fishes 1988, 22, 179-192. [CrossRef]

20. Hodges, M.H.; Allendorf, F.W. Population genetics and pattern of larval dispersal of the endemic Hawaiian freshwater amphidromous gastropod Neritina granosa (Prosobranchia: Neritidae). Pac. Sci. 1998, 52, 237-249.

21. Benbow, M.E.; Orzetti, L.L.; McIntosh, M.D.; Burky, A.J. A note on cascade climbing of migrating goby and shrimp postlarvae in two Maui streams. Micronesica 2002, 34, 243-248.

22. McDowall, R.M. Hawaiian stream fishes: The role of amphidromy in history, ecology and conservation biology. Bishop Mus. Bull. Cult. Environ. Stud. 2007, 3, 3-9.

23. Brasher, A.M.D.; Luton, C.D.; Goodbred, S.L.; Wolff, R.H. Invasion patterns along elevation and urbanization gradients in Hawaiian streams. Trans. Am. Fish. Soc. 2006, 135, 1109-1129. [CrossRef] 
24. Maciolek, J.A. Shell character and habitat of nonmarine Hawaiian neritid snails. Micronesica 1978, 14, $209-214$.

25. Maciolek, J.A. Environmental features and biota of anchialine pools on Cape Kinau, Maui, Hawaii. Stygologia 1986, 2, 119-129.

26. Ford, J.L. Biology of a Hawaiian Fluvial Gastropod Neritina granosa Sowerby (Prosobranchia: Neritidae). Master's Thesis, University of Hawai'i at Manoa, Honolulu, HI, USA, 1979.

27. Brasher, A.M. Life History Characteristics of the Native Hawaiian Stream snail Neritina Granosa (Hīhīwai). Technical Report 114; Cooperative National Park Resources Studies Unit, University of Hawai'i at Manoa: Honolulu, HI, USA, 1997.

28. Titcomb, M.; Fellowes, D.B.; Pukui, M.K.; Devaney, D.M. Native use of marine invertebrates in Old Hawaii. Pac. Sci. 1978, 32, 325-386.

29. Miike, L.H. Water and the Law in Hawai'i; University of Hawaii Press: Honolulu, HI, USA, 2004; ISBN 0-8248-2811-9.

30. Forman, D.M.; Serrano, S.K. Traditional and customary access and gathering rights. In Native Hawaiian Law: A Treatise; Kamehameha Publishing: Honolulu, HI, USA, 2015; pp. 779-854, ISBN 978-0-87336-342-6.

31. Bebler, M.H.; Foltz, D.W. Genetic diversity in Hawaiian stream macroinvertebrates. Micronesica 2004, 37, 119-128.

32. Quintero-Galvis, J.; Castro, L.R. Molecular phylogeny of the Neritidae (Gastropoda: Neritimorpha) based on the mitochondrial genes cytochrome oxidase I (COI) and 16S rRNA. Acta Biológica Colomb. 2013, 18, 307-317.

33. Arquez, M.; Colgan, D.; Castro, L.R. Sequence and comparison of mitochondrial genomes in the genus Nerita (Gastropoda: Neritimorpha: Neritidae) and phylogenetic considerations among gastropods. Mar. Genom. 2014, 15, 45-54. [CrossRef] [PubMed]

34. Uribe, J.E.; Colgan, D.; Castro, L.R.; Kano, Y.; Zardoya, R. Phylogenetic relationships among superfamilies of Neritimorpha (Mollusca: Gastropoda). Mol. Phylogenet. Evol. 2016, 104, 21-31. [CrossRef]

35. Stockwell, C.A.; Hendry, A.P.; Kinnison, M.T. Contemporary evolution meets conservation biology. Trends Ecol. Evol. 2003, 18, 94-101. [CrossRef]

36. Fraser, D.J.; Coon, T.; Prince, M.R.; Dion, R.; Bernatchez, L. Integrating traditional and evolutionary knowledge in biodiversity conservation: A population level case study. Ecol. Soc. 2006, 11, 4. [CrossRef]

37. Kinnison, M.T.; Hendry, A.P.; Stockwell, C.A. Contemporary evolution meets conservation biology II: Impediments to integration and application. Ecol. Res. 2007, 22, 947-954. [CrossRef]

38. Ely, C.V.; de Loreto Bordignon, S.A.; Trevisan, R.; Boldrini, I.I. Implications of poor taxonomy in conservation. J. Nat. Conserv. 2017, 36, 10-13. [CrossRef]

39. Cowie, R.H.; Evenhuis, N.L.; Christensen, C.C. Catalog of the Native Land and Freshwater Molluscs of the Hawaiian Islands; Backhuys Publishers: Leiden, The Netherlands, 1995; p. 204, ISBN 90-73348-43-9.

40. Christensen, C.C. Type species designation for Pelagolimnaea Germain, 1928, and a correction regarding the type species of Pseudisidora Thiele, 1931 (Gastropoda: Basommatophora: Lymnaeidae). Bishop Mus. Occas. Pap. 2015, 116, 53-56.

41. Hubendick, B. Hawaiian Lymnaeidae. Bishop Mus. Occas. Pap. 1952, 20, 307-328.

42. Morrison, J.P.E. Notes on Hawaiian Lymnaeidae. Malacol. Rev. 1968, 1, 31-33.

43. United States Fish \& Wildlife Service. Recovery Plan for the Newcomb's Snail (Erinna newcombi); U.S. Fish and Wildlife Service: Portland, OR, USA, 2006; pp. i-vi, 1-52.

44. Smith, R.; Seddon, M.B. Erinna newcombi. The IUCN Red List of Threatened Species 2003, e.T42392A10690568. Available online: https:/ / dx.doi.org/10.2305/IUCN.UK.2003.RLTS.T42392A10690568.en (accessed on 16 March 2021).

45. Christensen, C.C. The status of Tryonia porrecta (Mighels, 1845) in the Hawaiian Islands (Gastropoda: Cochliopidae). In Abstract volume, Proceedings of the World Congress of Malacology, Pacific Grove, CA, USA, 11-16 August 2019; California Academy of Sciences: San Francisco, CA, USA; p. 41.

46. Hershler, R. Systematics of the North and Central American aquatic snail genus Tryonia (Rissooidea: Hydrobiidae). Smithson. Contrib. Zool. 2001, 612,1-53. [CrossRef]

47. Burney, D.A.; James, H.F.; Burney, L.P.; Olson, S.L.; Kikuchi, W.; Wagner, W.L.; Burney, M.; McCloskey, D.; Kikuchi, D.; Grady, F.V.; et al. Fossil evidence for a diverse biota from Kauai and its transformation since human arrival. Ecol. Monogr. 2001, 71, 615-641. [CrossRef]

48. Bellanova, P.; Frenken, M.; Richmond, B.; Schwarzbauer, J.; La Selle, S.; Griswold, F.; Jaffe, B.; Nelson, A.; Reicherter, K. Organic geochemical investigation of far-field tsunami deposits of the Kahana Valley, Oahu, Hawaii. Sedimentology 2020, 67, 1230-1248. [CrossRef]

49. La Selle, S.; Richmond, B.M.; Jaffe, B.E.; Nelson, A.R.; Griswold, F.R.; Arcos, M.E.M.; Chague, C.; Bishop, J.M.; Bellanova, P.; Kane, H.H.; et al. Sedimentary evidence of prehistoric distant-source tsunamis in the Hawaiian Islands. Sedimentology 2020, 67, 1249-1273. [CrossRef]

50. Cowie, R.H. Catalog and bibliography of the nonindigenous nonmarine snails and slugs of the Hawaiian Islands. Bishop Mus. Occas. Pap. 1997, 50, 1-66.

51. Kirch, P.V. When did the Polynesians settle Hawaii? A review of 150 years of scholarly inquiry and a tentative answer. Hawaii. Archaeol. 2011, 12, 3-26.

52. Athens, J.S.; Rieth, T.M.; Dye, T.S. A paleoenvironmental and archaeological model-based age estimate for the colonization of Hawaii. Am. Antiq. 2014, 79, 144-155. [CrossRef]

53. Christensen, C.C. Alien freshwater clams in the Hawaiian Islands. Bishop Mus. Occas. Pap. 2016, 118, 1-4. 
54. Christensen, C.C.; Athens, J.S.; Kahn, J.G. Ancient aliens: The globally invasive aquatic snails Melanoides tuberculata (Müller, 1774) and Tarebia granifera (Lamarck, 1816) in prehistoric Polynesia. In Programs and Abstracts, Proceedings of the American Malacological Society E Western Society of Malacologists 2018 Annual Meeting, Honolulu, HI, USA, 19-23 June 2018; Bishop Museum: Honolulu, HI, USA; p. 35.

55. Hayes, K.A.; Yeung, N.W.; Kim, J.R.; Cowie, R.H. New records of alien Gastropoda in the Hawaiian Islands: 1996-2010. Bishop Mus. Occas. Pap. 2012, 112, 21-28.

56. Kirch, P.V. The impact of the prehistoric Polynesians on the Hawaiian ecosystem. Pac. Sci. 1982, 36, 1-14.

57. Athens, J.S.; Tuggle, H.D.; Ward, J.V.; Welch, D.J. Avifaunal extinctions, vegetation change, and Polynesian impacts in prehistoric Hawaii. Archaeol. Ocean. 2002, 37, 57-78. [CrossRef]

58. Athens, J.S. Rattus exulans and the catastrophic disappearance of Hawaii's native lowland forest. Biol. Invasions 2009, 11, 1489-1501. [CrossRef]

59. Olson, S.L.; James, H.F. Fossil birds from the Hawaiian Islands: Evidence for wholesale extinction by man before Western contact. Science 1982, 217, 633-635. [CrossRef] [PubMed]

60. Christensen, C.C.; Kirch, P.V. Nonmarine mollusks and ecological change at Barbers Point, O'ahu, Hawai'i. Bishop Mus. Occas. Pap. 1986, 56, 52-80.

61. Earle, T. Prehistoric irrigation in the Hawaiian Islands: An evaluation of evolutionary significance. Archaeol. Phys. Anthropol. Ocean. 1980, 15, 1-28.

62. Kirch, P.V. Feathered Gods and Fishhooks: An Introduction to Hawaiian Archaeology and Prehistory; University of Hawaii Press: Honolulu, HI, USA, 1985; ISBN 0-8248-0981-5.

63. Müller, J.G.; Ogneva-Himmelberger, Y.; Lloyd, S.; Reed, J.M. Predicting pre-historic taro (Colocasia esculenta var. antiquorum) lo'i in Hawaii. Econ. Bot. 2010, 64, 22-33. [CrossRef]

64. Olson, S.L.; James, H.F. Prodromus of the fossil avifauna of the Hawaiian Islands. Smithson. Contrib. Zool. 1982, 365, 1-59. [CrossRef]

65. Wilcox, C. Sugar Water: Hawaii's Plantation Ditches; University of Hawai'i Press: Honolulu, HI, USA, 1996; ISBN 0-8248-1783-4.

66. Sproat, D.K. From wai to kānāwai: Water law in Hawaii. In Native Hawaiian Law: A Treatise; Kamehameha Publishing: Honolulu, HI, USA, 2015; pp. 525-610, ISBN 978-0-87336-342-6.

67. MacLennan, C.A. Sovereign Sugar: Industry and Environment in Hawai'i; University of Hawaii Press: Honolulu, HI, USA, 2014; ISBN 978-0-8248-3949-9.

68. McIntosh, M.D.; Benbow, M.E.; Burky, A.J. Effects of stream diversions on riffle macroinvertebrate communities in a Maui, Hawaii, stream. River Res. Appl. 2002, 18, 569-581. [CrossRef]

69. Gingerich, S.B.; Wolff, R.H. Effects of Surface-Water Diversions on Habitat Availability for Native Macrofauna, Northeast Maui, Hawaii. United States Geological Survey Scientific Investigations Report 2005-5213; U.S. Geological Survey: Reston, VA, USA, 2005.

70. United States Fish and Wildlife Service. Endangered and threatened wildlife and plants: Determination of threatened status for Newcomb's snail from the Hawaiian Islands. Fed. Regist. 2000, 65, 4162-4169.

71. United States Fish and Wildlife Service. Endangered and threatened wildlife and plants: Designation of critical habitat for the Newcomb's snail. Final rule. Fed. Regist. 2002, 67, 54026-54056.

72. Clilverd, H.M.; Tsang, Y.-P.; Infante, D.M.; Lynch, A.J.; Strauch, A.M. Long-term streamflow trends in Hawaii and implications for native stream fauna. Hydrol. Process. 2019, 33, 699-719. [CrossRef]

73. Van Rees, C.B.; Reed, J.M. Wetland loss in Hawaii since human settlement. Wetlands 2014, 34, 335-350. [CrossRef]

74. Hershler, R.; Liu, H.-P.; Carlton, J.T.; Cohen, A.N.; Davis, C.B.; Sorenson, J.; Weedman, D. New discoveries of introduced and cryptogenic fresh and brackish water gastropods (Caenogastropoda: Cochliopidae) in the western United States. Aquat. Invasions 2015, 10, 147-156. [CrossRef]

75. Yamamoto, M.N.; Tagawa, A.W. Hawaii's Native and Exotic Freshwater Animals; Mutual Publishing: Honolulu, HI, USA, 2000; ISBN 1-56647-342-X.

76. Staples, G.W.; Cowie, R.H. Hawai'i's Invasive Species; Mutual Publishing: Honolulu, HI, USA, 2001; ISBN 1-56647-5104.

77. Cowie, R.H. Non-indigenous land and freshwater molluscs in the islands of the Pacific: Conservation impacts and threats. In Invasive Species in the Pacific: A Technical Review and Draft Regional Strategy; Sherley, G., Ed.; South Pacific Regional Environment Program: Apia, Samoa, 2000; pp. 143-164, ISBN 982-04-0214-X.

78. Funasaki, G.Y.; Lai, P.-Y.; Nakahara, L.M.; Beardsley, J.W.; Ota, A.K. A review of biological control introductions in Hawaii: 1890 to 1985. Proc. Hawaii. Entomol. Soc. 1988, 28, 105-160.

79. Meyer, W.M., III; Yeung, N.W.; Slapcinsky, J.; Hayes, K.A. Two for one: Inadvertent introduction of Euglandina species during failed bio-control efforts in Hawaii. Biol. Invasions 2017, 19, 1399-1405. [CrossRef]

80. Clarke, B.; Murray, J.; Johnson, M.S. The extinction of endemic species by a program of biological control. Pac. Sci. 1984, 38, 97-104.

81. United States Fish and Wildlife Service. Recovery Plan: Oahu Tree Snails of the Genus Achatinella; U.S. Fish and Wildlife Service, Region 1: Portland, OR, USA, 1993; pp. i-vi, 1-64, A1-A64.

82. Gerlach, J.; Barker, G.M.; Bick, C.S.; Bouchet, P.; Brodie, G.; Christensen, C.C.; Collins, T.; Coote, T.; Cowie, R.H.; Fiedler, G.C.; et al. Negative impacts of invasive predators used as biological control agents against the pest snail Lissachatina fulica: The snail Euglandina 'rosea' and the flatworm Platydemus manokwari. Biol. Invasions 2021, 23, 997-1031. [CrossRef] 
83. Kinzie, R.A., III. Predation by the introduced carnivorous snail Euglandina rosea (Ferussac) on endemic aquatic lymnaeid snails in Hawaii. Biol. Conserv. 1992, 60, 149-155. [CrossRef]

84. Alicata, J.E. Parasitic Infections of Man and Animals in Hawaii; Technical Bulletin 61; Hawaii Agricultural Experiment Station, College of Agriculture, University of Hawaii: Honolulu, HI, USA, 1964; pp. 1-138.

85. Knutson, L.V.; Vala, J.-C. Biology of Snail-Killing Sciomyzidae Flies; Cambridge University Press: Cambridge, UK, 2011; pp. i-xix, 1-506, ISBN 978-0-521-86785-6.

86. Kim, J.Y.; Naboa, E.E.; Amidon, F.; Reeves, M.K.; Miller, S.E. Hawaiian Islands coastal ecosystems: Past, present and future. In Encyclopedia of the World's Biomes; Goldstein, M.I., DellaSalla, D.A., Eds.; Elsevier: Amsterdam, The Netherlands, 2021; Volume 1, pp. 157-174.

87. Mitchell, C.; Ogura, C.; Meadows, D.W.; Kane, A.; Strommer, L.; Fretz, S.; Leonard, D.; McClung, A. Hawaii's Comprehensive Wildlife Conservation Strategy; Department of Land and Natural Resources: Honolulu, HI, USA, 2005.

88. Gopalakrishnan, C.; Malla, P.B.; Khaleghi, G.H. The politics of water in Hawaii: An institutional appraisal. Int. J. Water Resour. Dev. 1996, 12, 297-310. [CrossRef]

89. Gopalakrishnan, C.; Levy, J.; Li, K.W.; Hipel, K.W. Water allocation among multiple stakeholders: Conflict analysis of the Waiahole Water Project, Hawaii. Int. J. Water Resour. Dev. 2005, 21, 283-295. [CrossRef]

90. Spengler, S.; Heskett, M.; Uyeno, D.; Struach, A. Balancing in- and off-stream uses of water in the Hawaiian Islands. WIT Trans. Ecol. Environ. 2017, 216, 15-26.

91. Alexander \& Baldwin, Inc. Proposed Lease (Water Lease) for the Nāhiku, Ke'anae, Honomanū, and Huelu License Areas. Draft Environmental Impact Statement; Volume 1, 2019. Available online: http:/ / oeqc2.doh.hawaii.gov/EA_EIS_Library/2019-09-23 -MA-DEIS-East-Maui-Water-Lease.pdf (accessed on 26 January 2021).

92. Kauai Island Utility Cooperative. Waiahi Hydropower Long-Term Water Lease; Draft Environmental Assessment: Kauai, HI, USA, 2019. Available online: http:/ / oeqc2.doh.hawaii.gov/Doc_Library/2019-12-08-KA-Republished-DEA-Waiahi-HydropowerLong-Term-Water-Lease.pdf (accessed on 26 January 2021).

93. Yeung, N.W.; Hayes, K.A. Biodiversity and extinction of Hawaiian land snails: How many are left now and what must we do to conserve them-a reply to Solem (1990). Integr. Comp. Biol. 2018, 58, 1157-1169. [CrossRef]

94. Yeung, N.W.; Slapcinsky, J.; Strong, E.E.; Kim, J.R.; Hayes, K.A. Overlooked but not forgotten: The first new extant species of Hawaiian land snail described in 60 years, Auriculella gagneorum sp. nov. (Achatinellidae, Auriculellinae). ZooKeys 2020, 950, 1-31. [CrossRef] [PubMed]

95. Hayes, K.A.; Slapcinsky, J.; Sischo, D.R.; Kim, J.R.; Yeung, N.W. The last known Endodonta species? Endodonta christenseni sp. nov. (Gastropoda: Endodontidae). Bishop Mus. Occas. Pap. 2020, 138, 1-15. 